\title{
PENINGKATAN PENGETAHUAN TENTANG AIDS PADA PEKERJA SEKS KOMERSIAL DI PANTI SOSIAL WANITA SURAKARTA
}

\author{
Endang Zulaicha Susilaningsih dan Enita Dewi \\ Jurusan Keperawatan - Fakultas Ilmu Kesehatan \\ Universitas Muhammadiyah Surakarta
}

\begin{abstract}
Improving of AIDS desease one of caused by limited of knowledge which the impact of their attitude. Free sex related to the number of HIV viral infecsious. The aim of the activity is improving of knowledge the commercial sex workers about AIDS desease. AIDS one of the impact commercial sex workes. The methodh of activity are lecture,discussion and consultation. The matherial of AIDS including definition, simptom and sign, treatment and preventive. The rresult of activity is the knowledge of commercial sex workers better than before health education.
\end{abstract}

Kata Kunci: penyakit AIDS, pengetahuan PSK

\section{PENDAHULAN}

\section{Analisis Situasi}

Angka kesakitan penyakit Acquired Immunodeficiency Syndrome (AIDS) di dunia semakin meningkat dari tahun ke tahun, tidak terkecuali di Indonesia. Salah satu penyebab penyakiy AIDS ini adalah hubungan sek bebas yang merupakan media penyebaran virus Human Immunodeficiency Virus (HIV) yang memunculkan gejala AIDS.

Diantara faktor yang berhubungan dengan meningkatnya sek bebas adalah pengangguran. Beberapa tahun terakhir ini pengangguran di Indonesia makin meningkat, baik yang mempunyai latar belakang pendidikan tinggi seperti sarjana misalnya maupun tingkat menengah kebawah seperti SLTA, SLTP dan SD. Akibat dari pengangguaran dan sklill atau ketrampilan yang tidak dimiliki menjadikan para penganggur mengambil jalan singkat dalam mencari uang untuk memenuhi kebutuhan hidup atau untuk memperoleh biaya hidup.

Salah satu cara yang ditempuh oleh para pengangguran wanita dengan keterampilan yang kurang adalah bekerja sebagai Pekerja Sek Komersial (PSK) atau pelacur, yang jumlahnya semakin meningkat. Di Surakarta setiap minggu didapatkan kurang lebih 40 sampai 50 orang PSK yang berhasil di razia (sumber Solo Pos, 15 Mei 2009)

Diantara dampak dari kebebasan perilaku seksual adalah penyakit AIDS yaitu adalah suatu keadaan dari kumpulan berbagai gejala penyakit yang disebabkan karena seseorang terinveksi virus yang disebut Human Immunodeficiency Virus (HIV). Di dunia jumlahnya semakin meningkat, sedangkan di Indonesia kasus penderita AIDS juga meningkat. Seorang yang terinfeksi virus HIV, bisa selama 10 tahun tidah 
menunjukan tanda dan gejala tetapi orang tersebut bisa menularkan pada orang lain. Oleh karena itu penting dilakukan pencegahan terjadinya infeksi virus ini dengan berbagai cara.

Kompleks Panti Sosial Karya Wanita (PSKW), Wanita Utama yang berlokasi di jalan Rajiman 624 Jongke Laweyan Surakarta merupakan tempat pelatihan (terapi singkat) bagi wanita penjaja seks yang terkena Operasi Penyakit Masyarakat yang dilakukan oleh aparat keamanan. Yayasan ini sudah berdiri sejak zaman keraton kasunanan Surakarta tahun 1971, kemudian pengelolaanya diambil alih oleh pemerintah di bawah Dinas Kesejahteraan Rakyat (Kesra) Pemerinah Provinsi Jawa tengah.

Jumlah PSK yang dibina di PSKW hanya menampung 56 orang. Biasanya PSK yang tertangkap harus menjalani terapi di PSKW yang berupa pelatiahan ketrampilan dan penyuluhan dari kerokhanian. Lama pembinaan dan pelatihan para PSK yang tertangkap operasi pekat ini bervariasi yaitu mulai dari 4 bulan sampai 9 bulan. Ada 2 periode pembinaan dalam 1 tahun yaitu selama 6 bulan.

Beberapa kegiatan yang ada di PSKW diantaranya yaitu: 1) Pembinaan mental, yang dilakukan oleh rokhniawan dan psikolog; 2) Keterampilan memasak yang dibina oleh guru dibidangnya (dari IKIP); 3) Ketrampilan menjahit oleh ahli boga (IKIP); 4) Ketrampilan berbusana dan rias oleh ahli dibidangnya; 5) dan tambahan lain yang belum terprogram. Tenaga pembina di PSKW sangat kurang, hanya ada 10 orang pembina dan tenaga yang lainya adalah tenaga administrasi lulusan SMA yang tidak mempunyai ketrampilan khusus. Di PSKW ini tenaga kesehatan seperti perawat atau dokter tetap belum ada.

\section{Perumusan Masalah}

Pengangguran yang tinggi dan sulitnya mendapatkan pekerjaan membuat seseorang akan mencari jalan pintas untuk mempertahankan hidupnya. Beberapa faktor yang berhubungan dengan hal tersebut adalah rendahnya hardskill dan softskill yang merpakan penentu utama seorang untuk berkreatifitas dan menjadikan angak pengangguaran tinggi.

Salah satu keputusan yang diambil ketika seorang mempertahankan hidupnya adalah hal yang mudah yang bisa dilakukan. Dalam pengambilan keputusan tersebut, hal yang paling berhubungan adalah tingkat pengetahuan. Sejumlah wanita pengangguran yang memutuskan untuk menjadi pekerja sek komersial (PSK) dalam mempertahankan hidupnya atau mencukupi kebutuhanya disebabkan kurangnya pengetahuan mereka tentang dampak dari perilaku menyimpang tersebut.

Selain hal tersebut perilaku kronis yang dihadapi beberapa yayasan panti karya wanita dalam membiana PSK adalah, PSK yang terjaring operasi pekat seharusnya menjalani pembinaan yang telah diprogramkan oleh PSKW yaitu 4 sampai 6 bulan untuk mendapatkan berbagai ketrampilan, kemudian digantikan oleh PSK yang baru bila ada, tetapi program pembinaan belum selesai banyak PSK yang melarikan diri atau pergi dengan berbagai alasan. Asumsi dari perilaku ini adalah ingin kembalinya PSK tersebut pada pekerjaan semula yaitu sebagai pekerja sek komersial, hal ini disebabkan belum tahunya dampak dari sek bebas ynag salah satunya adalah penyakit AIDS.

Pemecahan masalah dari ketidaktahuan tentang penyakit AIDS yang disebabkan virus HIV adalah dengan memberikan pendidikan kesehatan tentang definisi, penyebab, tanda dan gejala, akibat, pengobatan dan cara pencegahan penyakit tersebut. Dengan meningkatnya pengetahuan tentang penyakit AIDS diharapkan para pekerja sek komersial mencari alternatif pekerjaan yang lebih baik dan todak membahayakan diri dan lingkungan. 


\section{Tinjauan Pustaka}

Acquired Immunodeficiency Syndrome atau disingkat AIDS merupakan penyakit yang paling ditakuti akhir-akhir ini, sebenarnya AIDS sendiri bukan sebuah penyakit tetapi merupakan kumpulan dari berbagai penyakit. Menurut Brunner dan Suddarhtis (2000) Definisi dari AIDS adalah suatu keadaan dari kumpulan berbagai gejala penyakit yang disebabkan karena seseorang terinveksi virus yang disebut Human Immunodeficiency Virus (HIV). Sebenarnya kondisi AIDS tidak sama dengan infeksi HIV, tidak semua orang yang terinfeksi HIV akan menjadi AIDS. Sebelum terjadi kondisi AIDS seseorang yang terinfeksi HIV tidak akan menunjukkan tanda dan gejala yang nyata samapai beberapa tahun.

Hasil Survey Center for Desease Control (CDC), penderita AIDS 84\% berusia 25 sampai 49 tahun sedangkan sisanya anak dan orang tua. Pada tahun 1997 dilaporkan 374,656 orang di dunia meninggal karena AIDS dan tahun 1999 sejumlah 410.800 orang di dunia meninggal karena AIDS angka kematian yang disebabkan AIDS yang semakin meningkat dari tahun ke tahun, serta kejadiannya semakin merambah di berbagai negara.Sehingga setiap orang perlu mengenal apa AIDS itu, bagaimana mencegahnya agak meminimalkan penularan yang berawal dari diri-sendiri.

Faktor Resiko AIDS: Sebenarnya AIDS dapat mengenai siapa saja dimana saja tetapi penyebab yang paling sering adalah seseorang yang mempunyai faktor resiko tertularnya virus penyebab AIDS yaitu terinfeksi HIV. Adapun orang yang mempunyai faktor resiko terinfeksi virus HIV adalah Homosex (melakukan hubungan sex dengan sesama jenis pada laki-laki, Heterosex (berganti-ganti pasangan dalam melakukan hubungan sex), Biseksual. Dari berbagai hasil penelitian presentasi kejadian penyakit AIDS karena masalah seksual paling tinggi diantara penyebeb yang lain dan sesudahnya adalah pemakai obat-obatan intravena (misalnya Pecandu Narkoba, ), Penerima darah misalnya orang yang mempunyai penyakit yang harus selalu ditransfusi seperti anemia berat, gagal ginjal dansebagainya sedangkan darah yang ditransfusikan bisa terkontaminasi, Anak yang lahir dari ibu yang terinfeksi dan sebagainya.

Seorang yang akan didiagnosis AIDS akan dimulai dengan kontak dengan faktor resiko atau sebagai faktor resiko itu sendiri, Apabila faktor resikonya terkait dengan hubungan seksual misalnya, maka sekret (cairan semen yang terkontaminasi virus HIV) akan kontak dengan mukosa, kemudia Virus akan masuk melalui aliran darah menuju ke sel didalam tubuh seorang yang baru saja kontak dengan virus tersebut, didalam sel virus akan mengalami replikasi, dari mulai masuknya virus HIV seseorang akan mengalami kondisi yang disebut masa laten dimana sampai beberapa tahun sdeorang yang terinfeksi ini tidak akan menunjukan tanda dan gejala bahkan ada yang sampai sepuluh tahun. Apabila dalam masa ini diberi pengobatan (apapun jenis pengobatannya : Spiritual, medis, Kultural dansebagainya) akan mengalami perubahan tergantung berhasil atau tidaknya pengobatan tersebut. Apabila sampai masanya perkembangan virus dalam tubuh seseorang yang terkena infeksi tersebut maka akan terjadi dengan apa yang disebut AIDS.

Katagori AIDS: Aids dikatagorikan menjadi 3 yaitu 1). Katagori A dengan tanda dan Gejala Terinfeksi HIV dengan nilai sel $\mathrm{T}$ masih diatas 500/ul,Tidak menunjukan tanda dan gejala, Adanya kelainan pada kelenjar getah bening yaitu terdapat benjolan 1 cetimeter atau lebih selama 3 bulan. 2).Katagori B yaitu Terinfeksi HIV dengan nilai sel T 200 sampai dengan 499, ada beberapa gejala seperti dibawah ini diataranya: Demam sampai $38,5^{\circ} \mathrm{C}$, Diare 
tidak sembuh sembuh lebih dari satu bulan, terserang herpes, radang panggul, kangker cerviks, jamur disaluran cerna (candidiasis), mati rasa di daerah perifer tubuh, perdarahan dibawah kulit dan sebagainya. 3). Katagori C yaitu Disebut indikasi dari kondisi AIDS yaitu terinfeksi virus HIV dan nilai sel $\mathrm{T}$ dibawah 200 dan menunjukan tanda dan gejala dari AIDS.

\section{a. Tanda dan Gejala AIDS}

Seseorang yang sudah didiagnosis AIDS akan menderita berbagai penyakit pada organ tubuhnya, oleh sebab itu AIDS disebut kumpulan gejala penyakit. Gejala penyakit yang muncul pada penderita AIDS mulai dari keluhan dari ujung rambut sampai ujung kaki yang merupakan respon adanya gangguan pada berbagai organ tubuh. Gangguan pada organ saluran cerna akan muncul respon candidiasis, mual nafsu makan turun, diare dansebagainya. Sedangkan gangguan pada sistem pernafasan akan menampakan respon batuk, sesak nafas, nyeri dada, Tuberkulosis dan lain sebagainya. Respon dari gangguan pada syaraf akan terjadi enchepalophaty, pada sistem integumen(kulit) akan terjadi dermatitis, bula karena herpes, mengelupas dan nyeri pada kulit . Gejala lain yang muncul adalah mudah lelah, letih, depresi, gangguan konsep diri dan dan fungsi organ hormonal (endokrin).

\section{b. Penatalaksanaan AIDS}

Dalam menangani masalah AIDS harus holistik dan komprehensif, holistik dalam arti memandang manusia sebagai individu secara menyeluruh dengan kebutuhan bio-psiko-sosisl-kultural dan spiritual, sedangkan komprehensif adalah menyeluruh mulai dari pencegahan (preventif), pengobatan (kuratif) dan rehabilitatif .

Pencegahan penyakit AIDS adalah dengan menghindari faktor resiko yang menyebabkan terjadinya penyakit tersebut.
Apabila faktor resiko itu masalah seksual maka seorang untuk menghindari faktor resiko ini seyogyanya dengan melakukan hubungan seksual yang sehat. Misalnya melakukan hubungan seksual hanya dengan satu partner saja, Jangan melakukan hubungan seksual dengan pengguna obat terlarang, Hindari nonpenetrativsex (saling masturbasi, fantasi, filem sex), hindari kehamilan dengan pasangan HIV dan sebagainya.

Pengobatan yang telah dilaksanakan di negara maju pengobatan pada penderiata AIDS dimaksudkan untuk menghambat replikasi virus HIV bukan membunuh virus tersebut. Telah dijelaskan didepan bahwa pengobatan AIDS harus secara holistik dan komprehensif, dengan demikian apabila pengobatan ditinjau dari bidang medis maka seorang dokter akan memberikan obat sesuai dengan diagnosa medis yang ditemukan untuk meminimalkan tanda da gejala/ keluhan pasien yang muncul, demikian juga bidang keperawatan akan merawat pasien AIDS sesuai dengan diagnosa keperawatan yang muncul berdasarkan tanda dan gejala pula. Pengobatan yang paling berhasil pada akhir-akhir ini adalah pendekatan spiritual misalnya melalui Zikir dan sebagainya. Menurut pendapat para pakar spiritual ini zikir akan meningkatkan jumlah sel T Helper dalam tubuh seorang penderita AIDS. Dengan demikian daya tahan tubuhnya akan meningkat.

Respon seorang yang terinfeksi virus HIV mulai dari gejala dan tanda yang tidak tampak sampai dengan terlihat tanda dan gejala yang jelas. Penyakit yang dikenal dengan AIDS ini apabila belum sampai pada kondisi yang berat bisa disembuhkan dengan berbagai cara dan apabila belum terjadi dapat dicegah dengan menghindari berbagai faktor resiko. Pengobatan yang dilakukan haruslah secara holistik dan komprehensif. 


\section{Tujuan dan manfaat kegiatan}

Tujuan dari kegiatan ini adalah untuk memberikan pengetahuan tentang AIDS pada PSK agar mengerti bahwa salah satu dampak dari pekerja sek bebas adalah penyakit AIDS yang membahaya-kan jiwa.

Manfaat jangka pendek dari kegiatan ini adalah mendapatkan infor-Imasi baru tentang definisi, penyebab tanda dan gejala, penatalaksanaan, pengobatan serta pencegahan penyakit AIDS yang disebabkan virus HIV. Manfaat jangka panjang dari kegiatan ini agar peserta penyuluhan (Pekerja sek komersial yang dibina) ikut dalam pembinaan sepenuhnya di Panti Sosial Karya Wanita sampai selesai, dan peserta tidak kembali lagi menjadi Pekarja Sek Komersial.

\section{METODA PELAKSANAAN}

Metode kegiatan dalam penyuluhan ini adalah melalui ceramah, diskusi, konsultasi, pemecahan kasus. Kegiatan dimulai dengan pretes tentang penyakit AIDS (menggali pengetahuan peserta tentang penyakit AIDS), kemudian dilakukan, ceramah tentang pengertian, penyebab, tanda dan gejala, pengobatan, pencegahan penyakit AIDS dan terakhir ditutup dengan Post test menggali pengetahuan peserta tentang penyakit AIDS.

Evaluasi jangka pendek dari pelatihan ini adalah dengan cara mengukur peningkatan pengetahuan peserta penyuluhan yaitu para PSK (Pekerja Sek Komersial) dengan membandingkan tanya jawab antara sebelum diberikan penyuluhan dan sesedah penyuluhan. Evaluasi jangka panjang dengan memantau apakah para PSK yang sudah diberi penyuluhan kembali melakukan kegiatan dengan cara menanyakan ke PSKW setiap ada PEKAT. (operasi penyakit masyarakat).

\section{HASIL DAN PEMBAHASAN}

Penyuluhan AIDS pada pekerja sek komersial dilaksanakan di aula panti sosial karya wanita, penyuluhan berlangsung mulai pukul 0800 s.d 14.00. Jumlah peserta penyuluhan ada 16 orang yang terdiri dari beberapa wanita mulai dari tingkat pendidikan SD sampai SMA, Ada 2 orang mahasiswa yang kemudian pergi sebelum penyuluhan selesai. Peserta penyuluhan mempunyai masa kerja terendah kurang lebih 8 bulan dan masa kerja terlama 16 tahun.

Kegiatan penyuluhan tentang AIDS di PSKW Surakarta dimulai dengan pembukaan yang didalamnya berisi sambutan dari pimpinan PSKW dan dari dosen UMS . Kemudian sebelum materi disajikan dilakukan tanya jawab tentang AIDS untuk menggali pengetahuan para peserta penyuluihan tentang penyakit AIDS atau HIV. Semua peserta antusias mengikuti tanya jawab sebelum materi diberikan. Setelah diberikan penyuluhan kesehatan tentang pengertian, tanda dan gejala, pengobatan dan pencegahan melalui ceramah, diskusi dan simulasi, selanjutnya semua peserta mengikuti postes yang berupa pertanyaan terbuka berdasarkan pedoman tersetruktur yang sudah disediakan.

Hasil jawaban dari pertanyaan secara subyektif lebih dari $60 \%$ peserta penyuluhan kesehatan mampu menjawab yang diberikan pemateri dan para fasilitator secara umum. Pertanyaan tentang pengertian AIDS bisa dijawab oleh $90 \%$ peserta, pertanyaan tentang penyebab AIDS bisa dijawab oleh $60 \%$ lebih dari 5 penyebab dan 50\% bisa menjawab 3 penyebab. Pertanyaan tanda dan gejala bisa dijawab oleh kurang lebih $75 \%$ peserta yang menyebutkan 5 tanta dan gejala dan 40\% menyebutkan 3 tanda dan gejala. Pertanyaan tentang pengobatan dan pencegahan semua peserta penyuluhan (100\%) bisa menjawab.

Hasil kegiatan penyuluhan tentang AIDS secara kualitatif menunjukan adanya peningkatan pengetahuan peserta penyuluhan tentang materi yang diajarkan hal ini ditunjukan dengan bisa terjawabnya semua pertanyaan yang diajukan ketika evaluasi. 
Keberhasilan yang lain bisa tampak ketika diskusi setelah pelatihan dibandingkan dengan reaksi saat penyuluhan tingkat pengetahuan diawal penyuluhan. Menurut Notoatmodjo (1996) Kegiatan proses belajar bisa terjadi dimana saja, melalui penyuluhan kesehatan seorang akan belajar dari tidak tahu menjadi tahu. Sedangkan menurut Effendy (1995) pendekatan edukatif akan dapat memacu perkembangan potensi. Pendidikan kesehatan adalah pendekatan edukatif untuk meningkatkan ketrampilan pemecahan masalah pada sekelompok orang yang membutuhkan informasi.

Keberhasilan kegiatan pelatihan ini disebabkan kooperatifnya peserta mulai dari awal pelatihan sampai selesai, alasan dari aktifnya partisipasi peserta tersebut adalah keingintahuan peserta tentang peserta tentang ilmu tentang AIDS yang diajarkan, selain alasan itu ada beberapa penjelasan dari peserta bahwa mereka ingin tahu pengobatanya apabila mereka terlanjur terkena AIDS. Para PSK yang rat-rata mempunyai pendidikan rendah menerima ilmu tentang AIDS hanya fokus dalam pengobatan sebab menurut mereka menjadi PSK adalah jalan hidup sehingga menurut para peserta penyuluhan mereka tidak bisa mencegahnya.

Konsultasi pribadi tentang pengobatan AIDS dengan fasilitator lebih menarik dan membutuhkan waktu lama, hal ini disebabkan para peserta malu berdiskusi secara terbuka dan mereka merasa takut wajahnya berubah jelek dan mati apabila terkena AIDS. Pertemuan dengan fasilitator dosen dan mahasiswa ini digunakan untuk konsultasi tentang beerbagai penyakit yang mereka alami seputar kulit dan kelamin.

\section{SIMPULAN DAN SARAN}

\section{Simpulan}

Peserta penyuluhan kesehatan tentang AIDS secara umum menunjukan adanya peningkatan pengetahuan. Tingkat pengetahuan peserta lebih baik setelah diberikan penyuluhan kesehatan daripada sebelum diberikan penyuluhan. Peserta penyuluhan lebih tertarik tentang bagaimana mengobati daripada mencegah AIDS, mereka juga tertarik untuk mendiskusikan beberapa penyakit kulit dan kelamin ketika dibuka forum diskusi, tanya jawab dan konsultasi.

\section{Saran}

Ilmu tentang AIDS khususnya pencegahan penting untuk ditekankan pada PSK, penyuluhan yang hanya sehari belum bisa menginternalisasi pada para PSK sebagai peserta penyuluhan, oleh sebab itu beberapa saran yang dianjurkan ditindaklanjuti adalah memprogramkan penyuluhan AIDS secara rutin dan terstruktur dengan berbagai media yang berbeda, menghadirkan penderita AIDS untuk testimony dan sharing dan bekerjasama dengan berbagai institusi unutk program pencegahan AIDS

\section{PERSANTUNAN}

Segala Puji bagi Allah Tuhan semesta alam, yang telah melimpahkan rahmatnya sehingga penulis dapat menyelesaikan laporan pengabdian masyarakat dengan judul "Peningkatan pengetahuan tentang AIDS Pada Pekerja Sek Komersial di Panti Sosial Wanita Surakarta.".Pendidikan kesehatan ini selain meningkatkan pengetahuan juga dalam rangka mencegah penularan penyakit AIDS pada masyarakat di wilayah Solo.

Dalam pelaksanaan kegiatan dan penyusunan laporan pengabdian masyarakat ini penulis banyak menerima bantuan, dukungan dan pengarahan dari berbagai pihak, sehingga dalam kesempatan ini penulis menyampaikan terima kasih kepada yang terhormat bapak Arif Widodo,M.Kes, 
selaku Dekan Fakultas Ilmu Kesehatan Universitas Muhammadiyah Surakarta yang telah memberikan kesempatan untuk melaksanakan tridarma perguruan tinggi, bapak Harun Joko Prayitno, M.Si., Selaku ketua Lembaga Penelitian Pengabdian Masyarakat Universitas Muhammadiyah Surakarta yang telah memfasilitasi pendanaan dalam kegiatan ini, pimpinan Panti sosial wanita surakarta yang telah bersedia bekerjasama dan mengijinkan dosen dan mahasiswa untuk berpartisipasi dalam program panti sosial melalui kegiatan ini, teman-teman yang telah mendukung terselasaikannya laporan ini

Semoga amal baiknya mendapat imbalan dari Allah SWT, dan semoga laporan ini dapat menjadi pengetahuan yang bermanfaat dalam bidang kesehatan khususnya keperawatan.

\section{DAFTAR PUSTAKA}

Burner \& Surdharthis. 2000. Medical-Surgikal Nursing. Philadelphia, J.B. Lippincott Company.

Ignatavius D,Workman M and Misler A. (1995. Medical- Surgikal Nursing Across The Healt Care Continum. Philadelphia, W.B. Saunders Company

Doengus, M. 1999. Nursing Care Plans. Philadelphia PA Davis Company 
